\title{
Adding to the freshwater red algal diversity in North America: Lympha mucosa gen. et sp. nov. (Batrachospermales, Rhodophyta)
}

\author{
Joshua R. Evans ${ }^{1, *}$, Iara S. Chapuis ${ }^{2}$ and Morgan L.Vis ${ }^{1}$ \\ ${ }^{1}$ Department of Environmental and Plant Biology, Ohio University, Athens, OH 45701, USA \\ ${ }^{2}$ Botany Department, Granada University, 18071, Granada, Spain
}

\begin{abstract}
The strictly freshwater red algal order Batrachospermales has undergone numerous taxonomic rearrangements in the recent past to rectify the paraphyly of its largest genus Batrachospermum. These systematic investigations have led to the description of new genera and species as well as re-circumscription of some taxa. Specimens collected from two locations in the southeastern USA were initially identified as being allied to Batrachospermum sensu lato, but could not be assigned to any recognized species. Representative $r b c \mathrm{~L}$ (plastid) and COI-5P (mitochondrion) sequences showed these specimens to be similar to each other and not closely matching the previously published sequence data for other Batrachospermum taxa. Comparison of sequence variation and morphology with a broader range of batrachospermalean taxa resulted in the proposal of a new monotypic genus Lympha mucosa gen. et sp. nov. to accommodate these specimens. Lympha mucosa is sister to members of a newly described genus Volatus, but the two genera are easily distinguished based on straight versus curved, twisted or spirally coiled carpogonial branch, respectively. This new taxon has morphological similarities to Batrachospermum sections Turfosa and Virescentia, but can be differentiated based on genetic divergence in $r b c \mathrm{~L}$ and COI-5P as well as a combination of morphological characters: dense, compressed whorls, axial carposporophytes with a single type of gonimoblast filament; cortication of the main axis closely appressed; and short, straight carpogonial branch arising from the pericentral cell and carpogonia with unstalked, lanceolate trichogynes. This new taxon adds to the freshwater red algal diversity of the southeastern USA, a region already known for biodiversity and high endemism of the aquatic flora and fauna. It is also a relevant new addition to the taxonomic knowledge of the freshwater red algal Batrachospermales.
\end{abstract}

Key Words: COI-5P; freshwater; Lympha; molecular phylogeny; rbcL; streams; systematics

Abbreviations: AL, Alabama; BI, Bayesian Inference; BS, bootstrap support; COI-5P, 5 ' region of the cytochrome $c$ oxidase subunit I; KY, Kentucky; ML, maximum likelihood; PP, posterior probability; rbcL, ribulose-1,5-biphosphate

\section{INTRODUCTION}

The red algal order Batrachospermales contains the greatest diversity of freshwater taxa and is distributed worldwide in streams and rivers (Sheath 1984, Kumano 2002). Current taxonomic research of this order has been focused on rectifying the paraphyly of the genus Batrachospermum Roth (Vis et al. 1998, Entwisle et al. 2009, 2016, Salomaki et al. 2014). For example, Salomaki et al. (2014) proposed a new genus Sheathia Salomaki \& M. L. terms of the Creative Commons Attribution Non-Commercial License (http://creativecommons.org/licenses/by-nc/3.0/) which permits unrestricted non-commercial use, distribution, and reproduction in any medium, provided the original work is properly cited.
Received June 2, 2017, Accepted September 8, 2017

*Corresponding Author

E-mail: je402115@ohio.edu

Tel: +1-740-591-9123, Fax: +1-740-593-1130 
Vis based on molecular data for species formerly classified in Batrachospermum section Helminthoidea. Likewise, Entwisle et al. (2016) proposed an expanded Nothocladus Skuja to accommodate many Australian endemics that had previously been included in Batrachospermum. In addition, a new genus Nocturama Entwisle \& M. L. Vis was established for Australian specimens not closely related to Nothocladus, but previously attributed to Batrachospermum (Entwisle et al. 2016). These studies, as well as others, have made significant progress in our understanding of the systematics of the Batrachospermales. However, further taxonomic revision is required for the resolution of the monophyly of Batrachospermum sensu lato, and new taxa are likely to be discovered with additional research.

North America is the continent with the greatest batrachospermalean richness of genera and sections of Batrachospermum (Vis 2016). However, only the genus Tuomeya is endemic to the continent with all others having members on other continents (Vis 2016). Thirtyeight infrageneric taxa were reported by Sheath and Vis (2015) with five additional taxa described by Chapuis et al. (2017), bringing the total to 43. North America appears to have a mix of both endemic and more cosmopolitan taxa with 17 (40\%) of those taxa being unique to this continent (Sheath and Vis 2015, Chapuis et al. 2017). Cosmopolitan taxa have been recorded with molecular data on more than one continent, such as Sirodotia suecica Kylin in Africa, Australasia, Europe, and North America (i.e., Lam et al. 2012); and Batrachospermum gelatinosum (Linnaeus) De Candolle throughout North America and Europe (House et al. 2010, Keil et al. 2015). Documentation with molecular data is important in determining the biogeography of some members of the Batrachospermales. For example, Sheathia boryana (Sirodot) Salomaki \& M. L. Vis (= Batrachospermum boryanum) was thought to be widespread in both North America and Europe, but the sequence data showed that samples from the two continents were genetically distinct, necessitating new species epithets to distinguish the North American specimens (Salomaki et al. 2014). The biogeographic patterns of these lineages are diverse, and further study of North American streams and rivers are expected to reveal more species and generic diversity.

In the southeastern United States, recent surveys have uncovered freshwater red algal diversity with new taxa proposed. Kumanoa holtonii M. L. Vis, Necchi, W. B. Chiasson et Entwisle was described from a stream in Alabama (Vis et al. 2012), as well as Volatus personatus I. S. Chapuis \& M. L. Vis and V. ulterior I. S. Chapuis \& M. L.
Vis from streams in Tennessee and Georgia, respectively, and Batrachospermum naiadis I. S. Chapuis \& M. L. Vis from Virginia (Chapuis et al. 2017). The current study continues this documentation of freshwater red algal diversity of the region with a study of specimens collected from streams in Kentucky and Alabama, USA. Based on the phylogenetic analysis of sequence data from the $r b c \mathrm{~L}$ and $5^{\prime}$ region of the cytochrome $c$ oxidase subunit I (COI$5 \mathrm{P})$ genes with previously described taxa, they were determined to have a unique placement within Batrachospermales. The combination of these molecular data with morphological assessment resulted in the proposal for Lympha mucosa gen. et sp. nov.

\section{MATERIALS AND METHODS}

\section{Sample collection}

Samples were collected from the Kinniconick River, Kentucky (KY), and Hill Creek, Alabama (AL), USA. Some stream water variables were measured, as follows: specific conductivity was measured with a Waterproof ECTestr low (Oakton, Vernon Hills, IL, USA), pH with a Waterproof pHTestr 30 Double Junction (Oakton), and temperature was taken with a liquid-in-glass thermometer. The algal collection was subdivided for DNA extraction, morphological examination and herbarium vouchers. Material for DNA extraction was cleaned of visible epiphytes, blotted dry, and immediately desiccated in silica gel. For morphological examination, material was placed in calcium carbonate-buffered $2.5 \%$ glutaraldehyde solution for preservation. The remaining material from each sample was used to prepare or mount herbarium vouchers deposited in the New York Botanical Garden Herbarium (NY) and the Floyd Bartley Herbarium (BHO) at Ohio University.

\section{DNA extraction and amplification}

Silica-dried samples were ground in liquid nitrogen using a mortar and pestle. DNA was extracted with a NucleoSpin Plant II kit (Macherey-Nagel, Düren, Germany) following the manufacturer's protocol. A large region of the plastid-encoded ribulose-1,5-biphosphate $(r b c \mathrm{~L}$, 1,282 bp) gene and mitochondrial-encoded, COI-5P (664 bp) gene were polymerase chain reaction (PCR) amplified. For the $r b c \mathrm{~L}$ marker, two different PCR systems were used as follows: $19 \mu \mathrm{L} \mathrm{dH_{2 }} \mathrm{O}, 25 \mu \mathrm{L}$ AmpliTaqGold master mix (Applied Biosystems, Carlsbad, CA, USA), $2.5 \mu \mathrm{L}$ each 
of the F160 and $r b c \mathrm{LR}$ primers (Vis et al. 1998) and $1 \mu \mathrm{L}$ of DNA for a total reaction volume of $50 \mu \mathrm{L}$, or $32.75 \mu \mathrm{L}$ $\mathrm{dH}_{2} \mathrm{O}, 5 \mu \mathrm{L} 10 \times$ buffer, $4 \mu \mathrm{L}$ dNTP, $4 \mu \mathrm{L} \mathrm{MgCl}{ }_{2}, 1.5 \mu \mathrm{L}$ each of the above primers, $0.75 \mu \mathrm{L}$ ExTaq (Takara Bio USA, Inc., Mountain View, CA, USA) and $1 \mu \mathrm{L}$ of DNA for a total reaction volume of $50 \mu \mathrm{L}$. The PCR parameters for $r b c \mathrm{~L}$ were as follows: initial denaturing at $95^{\circ} \mathrm{C}$ for $1 \mathrm{~min}$; 35 cycles of $93^{\circ} \mathrm{C}$ for $30 \mathrm{~s}, 50^{\circ} \mathrm{C}$ annealing for $30 \mathrm{~s}$ and $68^{\circ} \mathrm{C}$ elongation for $1 \mathrm{~min}$; and a final elongation at $72^{\circ} \mathrm{C}$ for $10 \mathrm{~min}$. For the COI-5P, the PCR mixture consisted of reagents and volumes used for the $r b c \mathrm{~L}$ marker, but with $2.5 \mu \mathrm{L} / 1.5 \mu \mathrm{L}$ each of the GazF1 and GazR1 primers (Saunders 2005). The PCR parameters were as follows: initial denaturing at $94^{\circ} \mathrm{C}$ for $1 \mathrm{~min} ; 40$ cycles of $94^{\circ} \mathrm{C}$ for $1 \mathrm{~min}, 50^{\circ} \mathrm{C}$ annealing for $1.5 \mathrm{~min}$, and $72^{\circ} \mathrm{C}$ extension for $1 \mathrm{~min}$; and a final extension at $72^{\circ} \mathrm{C}$ for $5 \mathrm{~min}$. Successful PCR products were purified with the UltraClean PCR Clean-up DNA purification kit (Mo Bio, Carlsbad, CA, USA) following the manufacturers protocol.

\section{Phylogenetic analyses}

The purified PCR products were sequenced at the Ohio University Genomics Facility using the PCR amplification primers. For $r b c \mathrm{~L}$, additional internal primers were used for sequencing. Sequences generated from AL specimens were sequenced with the internal primers F650 (Salomaki et al. 2014) and R897.test (5'-CGTGAGTATGTTGAATTACCTGC-3') and specimens from KY with F650 and R897.3 (Johnston et al. 2014). The raw data were edited and assembled using either Geneious V7.1.9 software (Drummond et al. 2010) or Sequencher 5.2.4 (Gene Codes Corp., Ann Arbor, MI, USA). All unique sequences were deposited in GenBank. In addition, GenBank was searched for other batrachospermalean taxa $(\mathrm{n}=31)$ with representative COI-5P and $r b c \mathrm{~L}$ sequences for phylogenetic analyses, and two species in the Thoreales were incorporated as outgroup taxa. Each individual gene and a concatenated alignment (1,946 bp) were sub- jected to Bayesian Inference analysis (BI) using MrBayes v3.2 (Ronquist et al. 2012) and maximum likelihood (ML) using RAxML (Stamatakis 2006) in Geneious plug-ins. For both analyses, genes and codon positions were partitioned (6 partitions) using the GTR + gamma model. The BI consisted of two independent simultaneous runs of one cold and three incrementally heated chains and $3 \times 10^{6}$ generations with sampling every 100 generations and the first 250 generated trees removed as burn-in to determine the posterior probabilities (PP). The ML analyses were conducted with the same model parameters and 1,000 bootstrap support (BS) replicates.

\section{Morphological analyses}

The morphological characters used in previous studies (Vis et al. 1995, Necchi and Vis 2012, Salomaki et al. 2014) were measured to compare these specimens within Batrachospermum and other related genera (Table 1). At least fifteen measurements were taken for whorl diameter, fascicle cell number, carposporophyte and carposporangium dimensions, and spermatium diameter, and at least seven measurements were taken for carpogonium dimensions. The characters were observed and documented using a BX40 Olympus microscope with an attached SC20 camera system (Olympus American Inc., Center Valley, PA, USA).

\section{RESULTS}

\section{Molecular analyses}

Specimens collected from both locations had representative $r b c \mathrm{~L}(1,282 \mathrm{bp}$ ) and COI-5P (664 bp) sequences generated. Multiple sequences for both markers were generated from additional specimens collected from both locations to confirm sequence similarity among specimens. Between the two locations, the $r b c \mathrm{~L}$ sequences dif-

Table 1. Morphometrics of vegetative and reproductive characters for Lympha mucosa gen. et sp. nov. from Kinniconick River, Kentucky (KY), and Hill Creek, Alabama (AL), USA

\begin{tabular}{|c|c|c|c|c|c|c|c|c|}
\hline \multirow{2}{*}{$\begin{array}{c}\text { Taxon } \\
\text { location }\end{array}$} & \multirow{2}{*}{$\begin{array}{l}\text { Whorl } \\
\text { diameter } \\
(\mu \mathrm{m})\end{array}$} & \multirow{2}{*}{$\begin{array}{c}\text { Spermatangium } \\
\text { diameter } \\
(\mu \mathrm{m})\end{array}$} & \multicolumn{2}{|c|}{ Carpogonium } & \multicolumn{2}{|c|}{ Carposporophyte } & \multicolumn{2}{|c|}{ Carposporangium } \\
\hline & & & $\begin{array}{c}\text { Diameter } \\
(\mu \mathrm{m})\end{array}$ & $\begin{array}{c}\text { Length } \\
(\mu \mathrm{m})\end{array}$ & $\begin{array}{c}\text { Diameter } \\
(\mu \mathrm{m})\end{array}$ & $\begin{array}{c}\text { Length } \\
(\mu \mathrm{m})\end{array}$ & $\begin{array}{l}\text { Diameter } \\
(\mu \mathrm{m})\end{array}$ & $\begin{array}{c}\text { Length } \\
(\mu \mathrm{m})\end{array}$ \\
\hline KY & $192 \pm 31$ & $6.4 \pm 0.9$ & $11.1 \pm 2.2$ & $48.9 \pm 6.5$ & $252 \pm 53$ & $212 \pm 35$ & $16.6 \pm 2.2$ & $25.1 \pm 2.5$ \\
\hline $\mathrm{AL}$ & $174 \pm 20$ & $6.7 \pm 1.2$ & $11.7 \pm 0.6$ & $36.8 \pm 4.5$ & $206 \pm 33$ & $179 \pm 28$ & $17.6 \pm 1.9$ & $28.1 \pm 3.1$ \\
\hline
\end{tabular}

Values are presented as mean \pm standard deviation.

For each population; $n=15$, except for carpogonial dimensions $(n=7)$. 


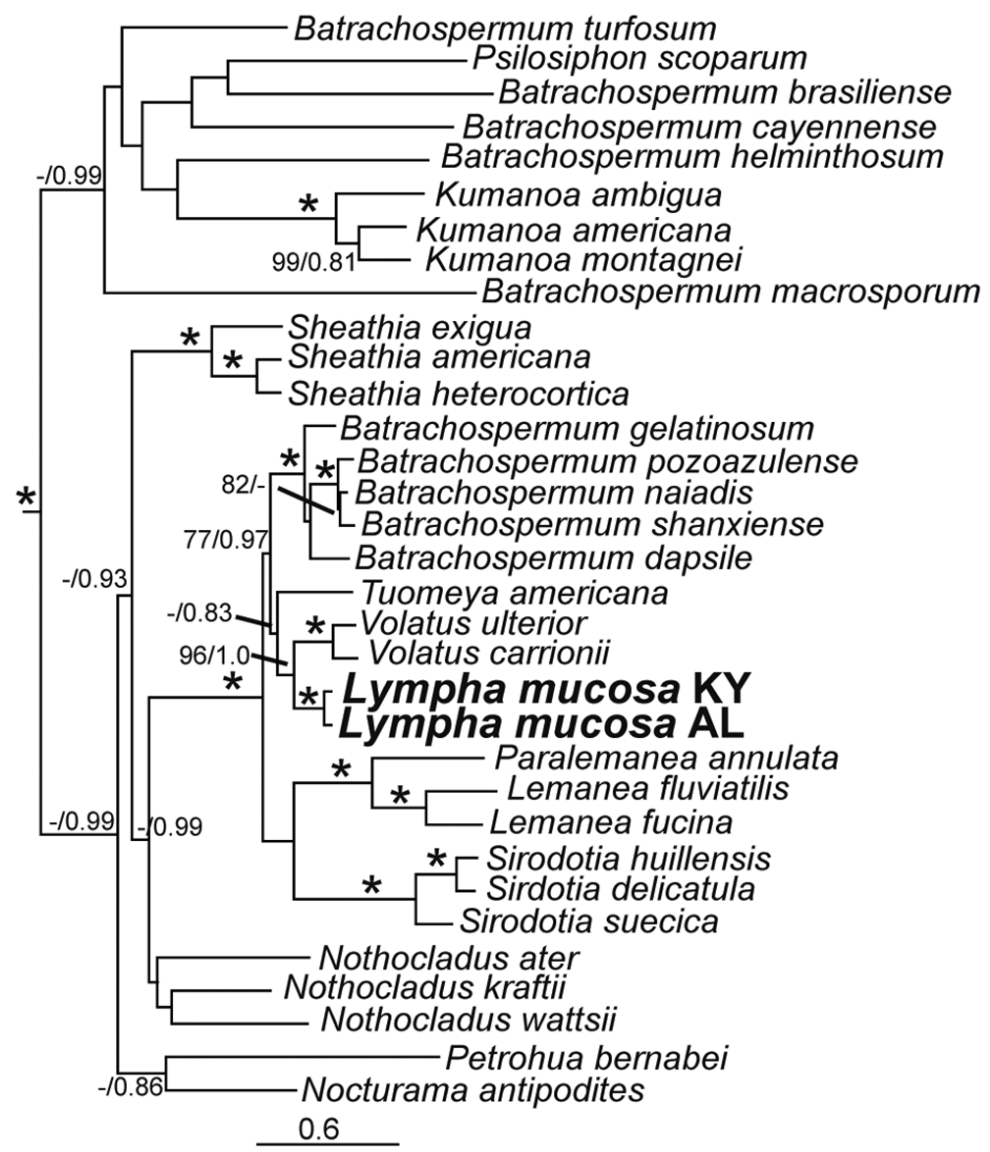

Fig. 1. Maximum likelihood (ML) phylogeny depicting the relationship of Lympha mucosa gen. et sp. nov. (in bold) with other genera of Batrachospermales based on COI-5P and rbcL concatenated sequence data. Support values are shown as bootstrap / posterior probability (PP) from Bayesian inference. Asterisks (*) indicates full support in both analyses, and dashes (-) indicate support $<70 \%$ bootstrap / 0.8 PP. Outgroup taxa of Thoreales (Thorea hispida, Nemalionopsis shawii) are not shown in the final tree. GenBank accession numbers for included taxa are available in Supplementary Table S1. KY, Kentucky; AL, Alabama.

fered at 8 sites ( $0.6 \%$ divergent) and the COI-5P at 23 sites (3.5\% divergent). The sequences for the two locations differed by $5.5 \%$ in the $r b c \mathrm{~L}$ and $8.9-9.0 \%$ in COI-5P from the nearest sequences in Volatus carrionii I. S. Chapuis \& M. L. Vis.

Phylogenetic trees inferred from BI and ML analyses of both the $r b c \mathrm{~L}$ and COI-5P showed similar topologies such that the two regions were concatenated for further analyses. Although both BI and ML analyses were conducted, only the tree generated from a concatenated alignment of the ML analyses is presented with the statistical support from both analyses (Fig. 1). Both the BI and ML analyses placed this novel genetic group (herein Lympha mucosa gen. et sp. nov.) as sister to the recently described genus Volatus (Chapuis et al. 2017) with high support (96 BS / 1.0 PP). The relationship of these genera with Tuomeya in the same clade is weakly supported (<70 BS / 0.8 PP), whereas the larger clade composed of these and Batrachospermum sensu stricto, Paralemanea, Lemanea, and Sirodotia was highly supported (100 BS / 1.0 PP).

\section{Morphological analyses}

Specimens from the KY population ranged in color from light green in the full sunlight to dark blue-green in shaded areas. The AL location was heavily shaded and the thalli collected were dark blue-green to almost black in color. Morphometric and qualitative characters were essentially similar among specimens from the two locations (Table 1, Fig. 2A-L). The thalli had reduced whorls, which became indistinct in older parts of the thallus and the carposporophytes protruded from the whorls (Fig. 2A-D \& F-H). This proportion of whorls to carposporophytes could be seen in the measurements of each with 


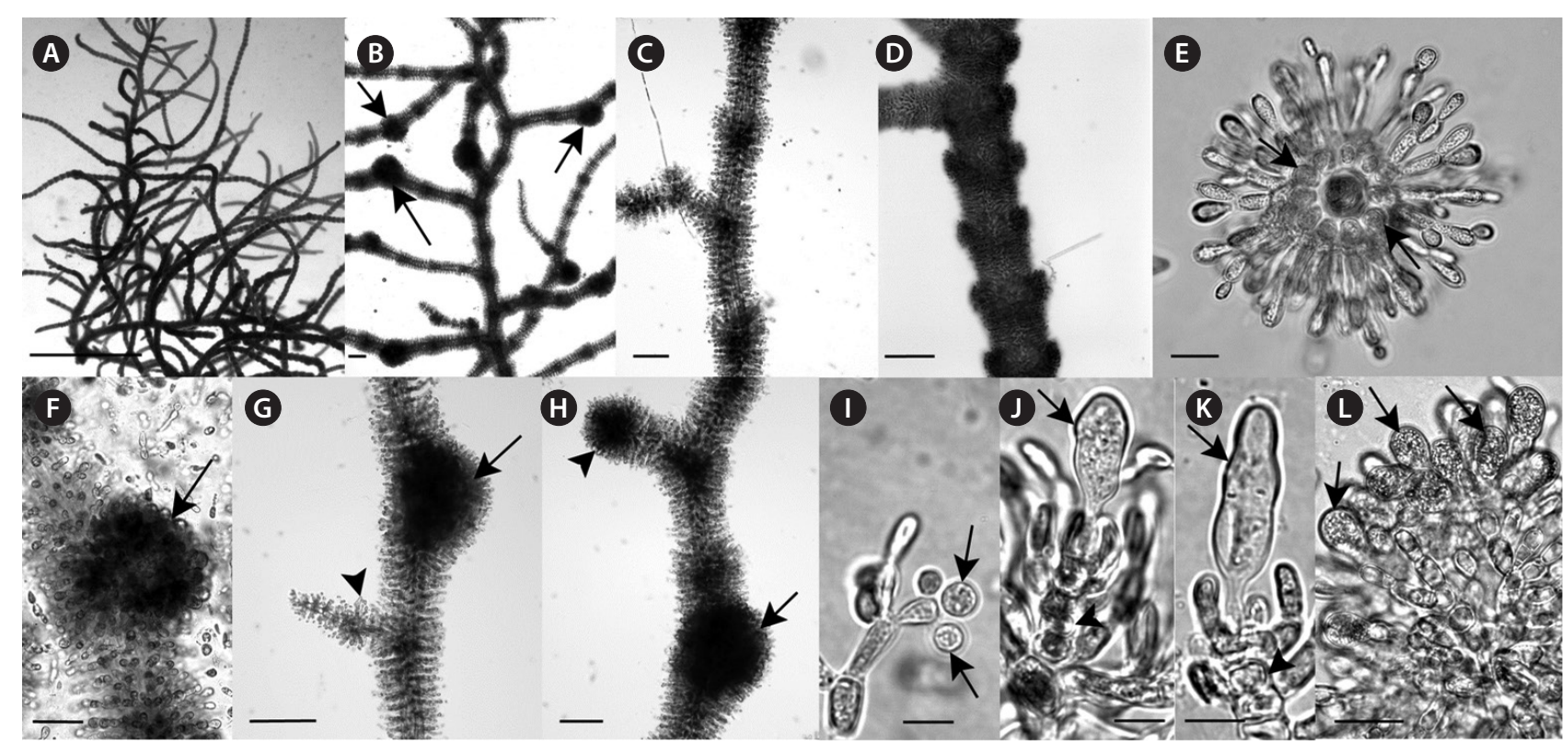

Fig. 2. Morphological characteristics of Lympha mucosa gen. et sp. nov. (A) Habit of thallus. (B) Habit of thallus with conspicuous carposporophytes (arrows). (C) Dense, elongate pear-shaped whorls with abundant secondary fascicles. (D) Confluent obconical whorls with abundant secondary fascicles. (E) X-section of thallus showing tightly packed cortical cells (arrows) with radiating short-celled fascicle that compose the whorl. (F) Immature, spherical carposporophyte (arrow) that is axial and protruding from the whorl. (G) Mature, dense, sub-spherical carposporophyte (arrow) protruding from whorl and carpogonium (arrowhead) on side branch. $(\mathrm{H})$ Mature, dense, spherical carposporophytes with one protruding from the whorl (arrow) and one seemingly at the termination of a branch (arrowhead). (I) Spermatangia (arrows) at a fascicle tip. (J) Immature carpogonium with a clavate trichogyne (arrow) on a short-celled straight carpogonial branch (arrowhead). (K) Mature carpogonium with an elongate-lanceolate trichogyne (arrow) on a short-celled straight carpogonial branch (arrowhead). (L) Compact carposporophyte with ovoid carposporangia (arrows) at branch tips. Scale bars represent: A, 5 mm; B, $200 \mu m ; C, D \& F, 100 \mu m ; E, 20 \mu m ; G \& H$, $150 \mu \mathrm{m} ; \mathrm{I}-\mathrm{K}, 10 \mu \mathrm{m} ; \mathrm{L}, 30 \mu \mathrm{m}$.

the whorls being primarily $<200 \mu \mathrm{m}$ and the carposporophyte diameters $>200 \mu \mathrm{m}$ (Table 1). The thalli were densely compact as seen in cross-section (Fig. 2E). Carpogonia were clavate to elongate-lanceolate (Fig. 2J \& K). The specimens from the two locations did differ in mean carpogonium length with much longer measurements from the KY location (Table 1). The spermatangia and carposporangia appearance and measurements were characteristic for batrachospermalean taxa (Table 1, Fig. 2I \& L). The suite of characters shown by these specimens is not present in any one genus or section of Batrachospermum. Therefore, a new genus and species are proposed.

\section{Taxonomy}

\section{Lympha gen. nov. J. R. Evans, I. S. Chapuis et M. L.Vis}

Description. Thalli ranging in color from light green in bright sunlight to dark blue-green to almost black in heavy shade. Thalli monoecious with reduced, dense, elongate pear-shaped or obconical or compressed whorls, becoming indistinct in older parts. Secondary fascicles very abundant. Spermatangia terminal or subterminal on primary fascicles or adjacent to the involucral filaments. Cortical cells of the main axis, appressed to the axis and cylindrical. Carpogonial branches straight, 1-3-celled, arising from the pericentral or proximal fascicle cells. Involucral filaments short and scarce. Carpogonia with clavate to elongate-lanceolate trichogynes. Carposporophyte axial, subspherical to spherical, and protruding from the whorl, carposporangia ovoid.

Etymology. The genus name is named in honor to the ancient Roman deity of fresh water, Lympha. She was the deity to whom one prayed to maintain the water supply.

\section{Lympha mucosa sp. nov. J. R. Evans, I. S. Chapuis et M. L.Vis}

Description. Thalli ranging in color from light green in bright sunlight to dark blue-green to almost black in heavy shade. Thalli monoecious with reduced, dense, elongate pear-shaped or obconical or compressed whorls, becoming indistinct in older parts. Mature whorls 154-223 $\mu \mathrm{m}$ in diameter. Primary fascicles composed of 
4-7 elliptical to fusiform cells. Secondary fascicles very abundant, covering the internode length. Cortical cells of the main axis, appressed to the axis and cylindrical. Spermatangia terminal or subterminal on primary fascicles or adjacent to the involucral filaments (see below), 6.4-7.0 $\mu \mathrm{m}$ in diameter. Carpogonial branches composed of 1-3 cells, straight, arising from the pericentral or proximal fascicle cells. Involucral filaments short (1-2 cells) and scarce. Carpogonia with clavate to elongate-lanceolate trichogynes, 9-13 $\mu \mathrm{m}$ in diameter and 37-49 $\mu \mathrm{m}$ long. Carposporophyte axial, 1 per whorl, dense, sub-spherical to spherical, protruding from the whorl, $173-305 \mu \mathrm{m}$ in diameter and 151-247 $\mu \mathrm{m}$ high; gonimoblast filaments composed of 2-3 cylindrical cells; carposporangia ovoid, 14-20 $\mu \mathrm{m}$ in diameter and 23-31 $\mu \mathrm{m}$ in length.

Holotype. USA, Kinniconick River, Kentucky, 38 $29^{\prime} 48^{\prime \prime}$ N, $83^{\circ} 15^{\prime} 26^{\prime \prime}$ W, Coll. M. L. Vis, W. B. Chiasson \& O. Necchi Jr., Aug 6, 2008, Holotype, NY Voucher Barcode 02137800, Isotype, BHO A-176.

Topotypes. Coll. A. Vandenbroek \& P. Contraras, Sep

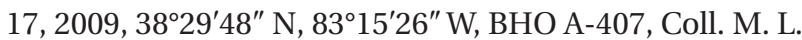

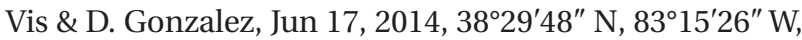
BHO A-1248.

Representative DNA barcode. GenBank KM593865 (rbcL), KM593873 (COI-5P).

Etymology. The species epithet is in recognition of the large quantities of cell wall polysaccharides that give the thallus a slimy feel and makes this species particularly difficult for extraction of DNA and RNA.

Specimens examined. In addition to the type material, a second population was examined. Hill Creek, Alabama, USA, $33.0536^{\circ} \mathrm{N}, 87.18726^{\circ} \mathrm{W}$, Coll. M. L. Vis, A. Rambani \& A. Vandenbroek, Jun 25, 2009, BHO A-0175 (GenBank accession $r b c$ L KM593850, COI-5P KM593868).

Distribution. This species has been collected in two locations of the southeastern United States, in Kentucky and Alabama, USA. The KY site is just north of the transition from the Cumberland Plateau to the Allegheny Plateau, whereas the AL site is at the southern end of the Cumberland Plateau.

Remarks. Stream conditions recorded at the KY site while collecting the holotype were as follows: water temperature $25^{\circ} \mathrm{C}, \mathrm{pH} 7.3$, and specific conductance of 140 $\mu \mathrm{S} \mathrm{cm}^{-1}$. Water conditions when topotypes were collected were as follows: water temperature 19 and $29^{\circ} \mathrm{C}, \mathrm{pH} 6.6$ and 8.3 and specific conductivity 110 and $120 \mu \mathrm{S} \mathrm{cm} \mathrm{cm}^{-1}$. The AL site had a water temperature of $30^{\circ} \mathrm{C}, \mathrm{pH} 8.1$, and specific conductance of $230 \mu \mathrm{S} \mathrm{cm}^{-1}$.

\section{DISCUSSION}

The molecular data for the two markers provided differing insights into the two populations of Lympha. For the $r b c \mathrm{~L}$ marker, the two populations differ only by eight sites across the 1,282 bp, with seven of those differences being pyrimidine transitions. This low level of divergence $(0.62 \%)$ solidly places sequences from both populations within the range of intraspecific variation reported in other Batrachospermales (e.g., Vis et al. 1998, 2012). The COI-5P marker was more divergent $(3.5 \%)$ between the two populations and certainly places these sequences within the range of divergence that constitutes distinct species in marine red algae, especially when morphological differences were also detected (Saunders 2005, Robba et al. 2006). However, the level of divergence reported in these populations is on the lower end of that range, and as much as $6.6 \%$ variation has been reported for intraspecific variation among Batrachospermum helminthosum populations throughout eastern North America (House et al. 2008). The combination of these previously accepted intraspecific limits for COI-5P in the Batrachospermales and a lack of discerning morphological and ecological characters provide little support for the hypothesis of two species, and conservatively we have chosen to describe a single species to accommodate these two populations.

In the phylogenetic analyses, Lympha was most closely related to Volatus (Chapuis et al. 2017). However, these two genera are easily distinguished based on morphology. The genus Volatus is similar to Kumanoa in that members of both genera produce curved, twisted or spirally coiled carpogonial branches (Necchi and Vis 2012, Chapuis et al. 2017). In contrast, L. mucosa produces straight carpogonial branches.

Lympha is morphologically most similar to members of Batrachospermum sections Virescentia and Turfosa (Sheath et al. 1994a, 1994c, Kumano 2002), and shared attributes include short, straight carpogonial branches, and axial carposporophytes that are typically 1-2 per whorl and larger than the whorl (Kumano 2002). However, most species of section Virescentia have well-developed whorls and carpogonia with stalked cylindrical trichogynes (Sheath et al. 1994a, Kumano 2002). Section Turfosa is more similar to Lympha in thallus habit with dense, compressed whorls becoming indistinct in older parts and carpogonium / trichogyne dimensions and shape. However, section Turfosa is characterized by the occurrence of two gonimoblast filament types (determinate and indeterminate) in the carposporophytes (Sheath et al. 1994c, Kumano 2002), which is not present in Lympha. In addi- 
tion, these taxa are genetically distinct from one another in comparisons of both markers. In the $r b c \mathrm{~L}, L$. mucosa is $12.7-12.9 \%$ divergent to Batrachospermum turfosum (section Turfosa) sequence data from France and French Guiana, and $13.7 \%$ divergent to B. helminthosum (section Virescentia). Similarily, L. mucosa is $15.6-15.7 \%$ and $18.7-$ $19.4 \%$ divergent in COI-5P to B. turfosum and B. helminthosum, respectively.

L. mucosa and the three species of Volatus exhibit similar biogeography and have been reported from North America. Volatus carrionii has a known distribution in both Europe and eastern Canada, while V. personatus and V. ulterior have been collected from streams in Georgia and Tennessee, USA. It is interesting that $L$. mucosa, $V$. personatus, and V. ulterior occur in the southeastern US, a region known for high biodiversity of aquatic organisms (Boschung and Mayden 2004, Williams et al. 2008). Indeed, this region already has remarkable diversity of freshwater red algae, with strictly eastern and southeastern North American endemics like Tuomeya americana and Kumanoa holtonii, respectively (Kaczmarczyk et al. 1992, Necchi and Vis 2012). Beyond these taxa with restricted distributions, there are many more with wider geographic distributions that inhabit this region with at least four species of Batrachospermum, three of Sheathia, four of Kumanoa as well as at least one Paralemanea species (Vis and Sheath 1992, 1997, Sheath et al. 1994a, 1994b, 1994c, Necchi and Vis 2012, Salomaki et al. 2014). Many taxa, including L. mucosa, are currently only known from one to two stream sites, but it is probable that more locations will be discovered with further thorough surveying of this region, especially in the Cumberland Plateau.

A likely reason for the diversity of the area for freshwater reds is that parts of the southeastern US served as a putative southern Pleistocene glacial refugium for plants and animals (Hewitt 1996, Church et al. 2003, Zamudio and Savage 2003, Griffin and Barrett 2004). House et al. (2010) hypothesized that Alabama was a southern refugium for Batrachospermum gelatinosum due to the greater genetic diversity in COI-5P within those populations than in more northern locations. These findings suggest that the southeastern US may be considered a 'hotspot' of batrachospermalean diversity in North America and further studies are warranted.

As a natural classification for batrachospermalean taxa is achieved, our understanding of the known distribution for these species is also subject to change. The once global distribution of Batrachospermum has now been largely restricted to the northern hemisphere, with new generic descriptions to accommodate most taxa previ- ously attributed to the genus that occur in the southern hemisphere (e.g., Entwisle et al. 2016). Likewise, new genera are being proposed for many northern hemisphere taxa (e.g., Salomaki et al. 2014, Chapuis et al. 2017). The proposal of Lympha mucosa gen. et sp. nov. supports the vast amount of genetic variation observed in species traditionally allied to Batrachospermum sensu lato, contributes to monophyly in Batrachospermales, and expands the freshwater red algal diversity in North America.

\section{ACKNOWLEDGEMENTS}

We thank Wayne Chiasson and Jason Bonham for help with lab work, and all of the collectors. NSF REU supplements to DEB 0640896 supported some of the field and laboratory research. ISC had funding provided by the Minister for Economy and Competitiveness through the project of the national plan I \& DpI (CGL2009-09563) and the FPI research grant to ISC (BES-2010-031303).

\section{SUPPLEMENTARY MATERIAL}

Supplementary Table S1. Genbank accession numbers for COI-5P and $r b c \mathrm{~L}$ sequence data of additional taxa from the Batrachospermales and Thoreales used for phylogenetic analyses (http://e-algae.org).

\section{REFERENCES}

Boschung, H. T. Jr. \& Mayden, R. L. 2004. Fishes of Alabama. Smithsonian Books, Washington, DC, 736 pp.

Chapuis, I. S., Necchi, O. Jr., Zuccarello, G. C., Xie, S. -L., Aboal, M., Sánchez Castillo, P. M. \&Vis, M. L. 2017. A new genus, Volatus and four new species of Batrachospermum sensu stricto (Batrachospermales, Rhodophyta). Phycologia 56:454-468.

Church, S. A., Kraus, J. M., Mitchell, J. C., Church, D. R. \& Taylor, D. R. 2003. Evidence for multiple Pleistocene refugia in the postglacial expansion of the eastern tiger salamander, Ambystoma tigrinum tigrinum. Evolution 57:372-383.

Drummond, A. J., Ashton, B., Cheung, M., Heled, J., Kearse, M., Moir, R., Stones-Havas, S., Thierer, T. \& Wilson, A. 2010. Geneious v7.0. Available from: http://www.geneious.com. Accessed Aug 1, 2017.

Entwisle, T. J., Johnston, E. T., Lam, D. W., Stewart, S. A. \& Vis, M. L. 2016. Nocturama gen. nov., Nothocladus s. lat. and 
other taxonomic novelties resulting from the further resolution of paraphyly in Australasian members of $\mathrm{Ba}$ trachospermum (Batrachospermales, Rhodophyta). J. Phycol. 52:384-396.

Entwisle, T. J., Vis, M. L., Chiasson, W. B., Necchi, O. Jr. \& Sherwood, A. R. 2009. Systematics of the Batrachospermales (Rhodophyta): a synthesis. J. Phycol. 45:704-715.

Griffin, S. R. \& Barrett, S. C. H. 2004. Post-glacial history of Trillium grandiflorum (Melantiaceae) in eastern North America: inferences from phylogeography. Am. J. Bot. 91:465-473.

Hewitt, G. M. 1996. Some genetic consequences of ice ages, and their role in divergence and speciation. Biol. J. Linn. Soc. 58:247-276.

House, D. L., Sherwood, A. R. \& Vis, M. L. 2008. Comparison of three organelle markers for phylogeographic inference in Batrachospermum helminthosum (Batrachospermales, Rhodophyta) from North America. Phycol. Res. 56:69-75.

House, D. L., Vandenbroek, A. M. \& Vis, M. L. 2010. Intraspecific genetic variation of Batrachospermum gelatinosum (Batrachospermales, Rhodophyta) in eastern North America. Phycologia 49:501-507.

Johnston, E. T., Lim, P. -E., Buhari, N., Keil, E. J., Djawad, M. I. \&Vis, M. L. 2014. Diversity of freshwater red algae (Rhodophyta) in Malaysia and Indonesia from morphological and molecular data. Phycologia 53:329-341.

Kaczmarczyk, D., Sheath, R. G. \& Cole, K. M. 1992. Distribution and systematics of the freshwater genus Tuomeya (Rhodophyta, Batrachospermaceae). J. Phycol. 28:850855.

Keil, E. J., Macy, T. R., Kwandrans, J., Eloranta, P., Tomás, P., Aboal, M. \&Vis, M. L. 2015. Phylogeography of Batrachospermum gelatinosum (Batrachospermales, Rhodophyta) shows postglacial expansion in Europe. Phycologia 54:176-182.

Kumano, S. 2002. Freshwater red algae of the world. Biopress Ltd., Bristol, 375 pp.

Lam, D. W., Entwisle, T. J., Eloranta, P., Kwandrans, J. \& Vis, M. L. 2012. Circumscription of species in the genus Sirodotia (Batrachospermales, Rhodophyta) based on molecular and morphological data. Eur. J. Phycol. 47:42-50.

Necchi, O. Jr. \& Vis, M. L. 2012. Monograph of the genus $\mathrm{Ku}$ manoa (Rhodophyta, Batrachospermales). Bibl. Phycol. 116:1-79.

Robba, L., Russell, S. J., Barker, G. L. \& Brodie, J. 2006. Assessing the use of the mitochondrial $\operatorname{cox} 1$ marker for use in DNA barcoding of red algae (Rhodophyta). Am. J. Bot. 93:1101-1108.

Ronquist, F., Teslenko, M., Van Der Mark, P., Ayres, D. L., Dar- ling, A., Höhna, S., Larget, B., Liu, L., Suchard, M. A. \& Huelsenbeck, J. P. 2012. MrBayes 3.2: efficient Bayesian phylogenetic inference and model choice across a large model space. Syst. Biol. 61:539-542.

Salomaki, E. D., Kwandrans, J., Eloranta, P. \& Vis, M. L. 2014. Molecular and morphological evidence for Sheathia gen. nov. (Batrachospermales, Rhodophyta) and three new species. J. Phycol. 50:526-542.

Saunders, G. W. 2005. Applying DNA barcoding to red macroalgae: a preliminary appraisal holds promise for future applications. Philos. Trans. R. Soc. Lond. B Biol. Sci. 360:1879-1888.

Sheath, R. G. 1984. The biology of freshwater red algae. Prog. Phycol. Res. 3:89-157.

Sheath, R. G. \& Vis, M. L. 2015. Red algae. In Wehr, J. D., Sheath, R. G. \& Kociolek, J. P. (Eds.) Freshwater Algae of North America. 2nd ed. Academic Press, San Diego, CA, pp. 237-264.

Sheath, R. G., Vis, M. L. \& Cole, K. M. 1994a. Distribution and systematics of Batrachospermum (Batrachospermales, Rhodophyta) in North America. 4. Section Virescentia. J. Phycol. 30:108-117.

Sheath, R. G., Vis, M. L. \& Cole, K. M. 1994b. Distribution and systematics of Batrachospermum (Batrachospermales, Rhodophyta) in North America. 5. Section Aristata. Phycologia 33:404-414.

Sheath, R. G., Vis, M. L. \& Cole, K. M. 1994c. Distribution and systematics of Batrachospermum (Batrachospermales, Rhodophyta) in North America. 6. Section Turfosa. J. Phycol. 30:872-884.

Stamatakis, A. 2006. RAxML-VI-HPC: maximum likelihoodbased phylogenetic analyseswith thousands of taxa and mixed models. Bioinformatics 22:2688-2690.

Vis, M. L. 2016. Biogeography of river algae. In Necchi, O. Jr. (Ed.) River Algae. Springer Nature, Dordrecht, pp. 219244.

Vis, M. L., Necchi, O. Jr., Chiasson, W. B. \& Entwisle, T. J. 2012. Molecular phylogeny of the genus Kumanoa (Batrachospermales, Rhodophyta). J. Phycol. 48:750-758.

Vis, M. L., Saunders, G. W., Sheath, R. G., Dunse, K. \& Entwisle, T. J. 1998. Phylogeny of the Batrachospermales (Rhodophyta) inferred from $r b c \mathrm{~L}$ and $18 \mathrm{~S}$ ribosomal DNA gene sequences. J. Phycol. 34:341-350.

Vis, M. L. \& Sheath, R. G. 1992. Systematics of the freshwater red algal family Lemaneaceae in North America. Phycologia 31:164-179.

Vis, M. L. \& Sheath, R. G. 1997. Biogeography of Batrachospermum gelatinosum (Batrachospermales, Rhodophyta) in North America based on molecular and morphological data. J. Phycol. 33:520-526. 
Vis, M. L., Sheath, R. G. \& Entwisle, T. J. 1995. Morphometric analysis of Batrachospermum section Batrachospermum (Batrachospermales, Rhodophyta) type specimens. Eur. J. Phycol. 30:35-55.

Williams, J. D., Bogan, A. E. \& Garner, J. T. 2008. Freshwater mussels of Alabama and the Mobile basin in Georgia,
Mississippi, and Tennessee. The University of Alabama Press, Tuscaloosa, AL, 960 pp.

Zamudio, K. R. \& Savage, W. K. 2003. Historical isolation, range expansion, and secondary contact of two highly divergent mitochondrial lineages in spotted salamanders (Ambystoma maculatum). Evolution 57:1631-1652. 